\title{
Holocene temperature variations inferred from six Antarctic ice cores
}

\author{
P. Giais, \\ Stable 1sotope Laboratory, Institute of Alpine and Arctic Research, University of Colorado, Boulder, CO 80303, U.S.A., \\ Laboratoire de Modelisation du Climat et de l'Environnemenl, C.E. Saclay, 91191 Gif-sur-Yutle Cedex, France, \\ and NOAACMDL Carbon Cycle Group, Boulder, CO 80303, U.S.A. \\ J. JOUZEL, \\ Stable Isotope Laboratory, Institute of Alpine and Artic Research, University of Colorado, Boulder, CO 80303, U.S.A., \\ and Laboratoire de Glaciologie et de Géophysique de l'Environnement, 38402 Saint-Martin-d'Ières Cedex, France \\ J.R. Petit, \\ Laboratoire de Glaciologie et de Géophysique de l'Environnement, 38402 Saint-Martin-d'Hères Cedex, France, and \\ Stable Isotope Laboratory, Institute of Alpine and Arctic Research, University of Colorado, Boulder, CO 80303, U.S.A. \\ V. LIPENKOV, \\ Insitule of Geography, Moscow 109017, Russia \\ J. W. C. WHite \\ Stable Isotope Laboratory, Institute of Alpine and Arctic Research, University of Colorado, Boulder, CO 8030.3, U.S.A.
}

\begin{abstract}
We have reconstructed temperature changes over the past 15000 years from ice-core data in Antarcica. We used measurements of the $\mathrm{D} / \mathrm{H}$ isotope ratio in ice as a proxy of temperature for central sites (Vostok, Dome $\mathrm{C}$ and Komsomolskaya) as well as coastal sites (D47, D15 and D10). First, we examined the dating of cach core and built up a common temporal framework for the ensemble of the data. Sccondly, we addressed the problem of inferring small-amplitude tempcrature fluctuations from the isotope data, in the light of noise-generating mechanisms involved in snow deposition. Temperature was reconstructed so as to minimize distortion created by the sampling of ice cores in the field. The seven ice cores studied vield an average temperature curve which can be put in perspective with nearby paleoclimatic records. The carly Holocene cxpcrienced climatcs warmer than today by $1-2^{\circ} \mathrm{C}$. 'The late Holocenc period shows more discernible, shorter-duration, temperature fluctuations, superimposed on a fairly stable "basc-line" tempcrature.
\end{abstract}

\section{INTRODUCTION}

Although Antarctic ice cores have provided a wealth of paleoclimate data for the past 200000 years, with the key advantage that ice cores are continuous paleoclimate recorders, little attention has becn given as yet to the Holocene interval. During the past 10000 years, climate proxies recorded in Antarctic ice all have fairly constant lcrels, with fluctuations typically one order of magnitude smaller than Pleistocene-Holocene changes. This is true for trace gases trapped in air bubbles, aerosols and dust content as well as for the concentration of stable isotopes $\mathrm{D}$ and ${ }^{18} \mathrm{O}$ in ice.

The primary objective of this paper is to discuss Holocene temperature changes from the isotope record of several ice cores. $\mathrm{D} / \mathrm{H}$ and ${ }^{18} \mathrm{O} /{ }^{16} \mathrm{O}$ ratios in ice are linearly related to local temperature and this makes it possible to reconstruct the temperaturc on a quantitative basis. However, the climatic signal contained in isotope data is embedded in noise related to snow-deposition processes. We need to separate the climatic information from the noise. We show in the following that only: fluctuations of duration longer than $\approx 500$ years are rclcvant for climate.

The ice cores we examined fall within two categories (Table 1; Fig. 1). "Deep ice cores" were drilled on the Antarctic plateau, where both the annual accumulation and ice motion are small. Such cores give access to very long climate rccords essentially exempt from ice-flow distortion. But, within the Holocene, deep ice cores offer only a limited time resolution. "Coastal ice cores" drilled along the margins of the icc sheet have greater accumulation rates and thus better time resolution. However, the regional ice flow is relatively fast and strongly affects the isotope profiles, as ice measured in the cores originates from upstream. Coastal ice cores integrate 


\begin{tabular}{|c|c|c|c|c|c|c|c|}
\hline & Vostok $3 G$ & Vostok $4 G$ & Dome $C$ & Komsomolskaya & $D-47$ & $D-15$ & $D-10$ \\
\hline \multirow{2}{*}{$\begin{array}{l}\text { Location } \\
\text { (lat./long.) }\end{array}$} & $72^{\circ} 28^{\prime} \mathrm{S}$ & $72^{\circ} 28^{\prime} \mathrm{S}$ & $74^{\circ} 39^{\prime} \mathrm{S}$ & $74^{\circ} 05^{\prime} \mathrm{S}$ & $67^{\circ} 23^{\prime} \mathrm{S}$ & $66^{\circ} 42^{\prime} \mathrm{S}$ & $66^{\circ} 42^{\prime} \mathrm{S}$ \\
\hline & $106^{\circ} 48^{\prime} \mathrm{E}$ & $106^{\circ} 48^{\prime} \mathrm{E}$ & $124^{\circ} 10^{\prime} \mathrm{F}$ & $97^{\circ} 29^{\prime} \mathrm{E}$ & $154^{\circ} 03^{\prime} \mathrm{E}$ & $139^{\circ} 46^{\prime} \mathrm{E}$ & $139^{\circ} 46^{\prime} \mathbf{E}$ \\
\hline $\begin{array}{l}\text { Elcvation } \\
\text { (m) }\end{array}$ & 3488 & 3488 & 32.50 & 3499 & 1.550 & 296 & 235 \\
\hline $\begin{array}{l}\text { Temperature } \\
\left.\quad{ }^{\circ} \mathrm{C}\right)\end{array}$ & -55.5 & -55.5 & -53.5 & -52.6 & -25.4 & -16.2 & -14.4 \\
\hline $\begin{array}{l}\text { Accumulation } \\
\qquad\left(\mathrm{g} \mathrm{cm}^{2} \mathrm{a}^{1}\right)\end{array}$ & 2.3 & 2.3 & 3.4 & 6.4 & 26 & 43 & 13 \\
\hline $\begin{array}{l}\text { Accumulation } \\
\text { determination }\end{array}$ & $\begin{array}{c}\text { Tambora } \\
\text { Legrand and } \\
\text { Delmas, 1987) }\end{array}$ & $\begin{array}{c}\text { Tambora } \\
\text { Legrand and } \\
\text { Delmas, 1987) }\end{array}$ & $\begin{array}{c}\text { Tambora } \\
\text { Legrand and } \\
\text { Delmas, 1987) }\end{array}$ & $\begin{array}{l}\beta+\text { stakes } \\
\text { (pers. comm., } \\
\text { M. Pourchet) }\end{array}$ & $\begin{array}{l}\text { Tambora } \\
\text { (pers. comm., } \\
\text { M. Legrand) }\end{array}$ & $\begin{array}{c}\beta+\text { stakes } \\
\text { Pettre and } \\
\text { others, } 1986)\end{array}$ & $\begin{array}{c}\beta+\text { stakes } \\
\text { Pettre and } \\
\text { others, 1986) }\end{array}$ \\
\hline $\begin{array}{l}\text { Core length } \\
\text { (m) }\end{array}$ & 950 & 2546 & 930 & 850 & 870 & $34 \bar{j}$ & 310 \\
\hline $\begin{array}{l}\text { Ice thickness } \\
\text { (m) }\end{array}$ & $\approx 3400$ & $\approx 3400$ & $\approx 3700$ & $\approx 3000$ & $\approx 1700$ & 390 & 310 \\
\hline $\begin{array}{l}\text { Surface-ice } \\
\text { velocity } \\
(\mathrm{ms})\end{array}$ & $\approx 5$ & $\approx \bar{j}$ & $\approx 0$ & - & 26 & $\approx 10$ & $\approx 10$ \\
\hline \multirow[t]{2}{*}{ Sampling } & $100 \mathrm{~cm}$ & $\begin{array}{l}100 \mathrm{~cm} \text { in the } \\
\text { Holocene }\end{array}$ & $200 \mathrm{~cm}$ & $\begin{array}{c}200 \mathrm{~cm} \text { every } \\
5 \mathrm{~m} \text { above } 725 \mathrm{~m}\end{array}$ & $\begin{array}{c}100 \mathrm{~cm} \text { above } \\
700 \mathrm{~m}\end{array}$ & $100 \mathrm{~cm}$ & $1 \mathrm{~m}$ \\
\hline & $\begin{array}{l}\text { gap between } \\
0 \text { and } 138 \mathrm{~m}\end{array}$ & $\begin{array}{l}50 \mathrm{~cm} \text { in the } \\
\text { deglaciation }\end{array}$ & $\begin{array}{c}65 \mathrm{~cm} \text { betwecn } \\
0 \text { and } 73 \mathrm{~m}\end{array}$ & $\begin{array}{l}500 \mathrm{~cm} \text { every } \\
25 \mathrm{~m} \text { below }\end{array}$ & $50 \mathrm{~cm}$ below & $\begin{array}{c}10 \mathrm{~cm} \text { above } \\
50 \mathrm{~m}\end{array}$ & $\begin{array}{l}\text { Non- } \\
\text { continuous }\end{array}$ \\
\hline $\begin{array}{l}\text { Glacial- } \\
\text { Holocene } \\
\text { boundary }\end{array}$ & $260 \mathrm{~m}$ & $260 \mathrm{~m}$ & $400 \mathrm{~m}$ & $\approx 680 \mathrm{~m}$ & Absent & Absent & $\approx 200 \mathrm{~m}$ \\
\hline Reference & $\begin{array}{l}\text { Lorius and } \\
\text { others, } 1985\end{array}$ & $\begin{array}{l}\text { Jouzel and } \\
\text { others, 1987b }\end{array}$ & $\begin{array}{l}\text { Lorius and } \\
\text { others, } 1979 \\
\text { Jouzel and } \\
\text { others, } 1982\end{array}$ & $\begin{array}{c}\text { Nicolaiev and } \\
\text { others, 1988; } \\
\text { Ciais and others, } \\
1992\end{array}$ & This paper & This paper & $\begin{array}{c}\text { Jouzel and } \\
\text { Mcrlivat, } 1977\end{array}$ \\
\hline
\end{tabular}

past variations in climate over an extended area.

The dating of the deep ice cores from Vostok and Dome $C$ has bcen based on icc-flow models over the last climatic cycle. For the Holocene, the dating needs to be examined in detail. Bccausc Holoccne ice represents a minor fraction of the total ice-sheet thickness, its chronology is dominated by accumulation rates, while such variables as bedrock topography or ice rheology are unimportant. The dating of coastal ice cores can also be addressed by models, which offer the advantage of being able to deconvolute the flow-related component from the climate-related component in the isotope profiles. Complications arise, however, at sites located on the icc-shcet margins because several distinct boundary conditions affect the ice dynamics. With the exception of D-10 and D-15, cach core presented in this study is dated separately and is independent from other paleoclimate records.

\section{ISOTOPE DATA}

The isotope data of the deep and coastal ice cores are presented in Table 1 and Figure 2. Further information on the cores (drilling technique and core recovery) can be found in the references provided. The ice cores of D-47 and D-15, respectively, drilled in 1988 and 1983 by the French Polar Expeditions, are presented for the first time in this paper. The dating of these cores is discussed in section 2.2 .

\section{ICE-CORE CHRONOLOGY}

\subsection{Deep ice cores}

Lack of seasonal variations in the isotope data at inland Anlartic sites

The snow deposition in Antarctica is much lower inland $\left(\approx 5 \mathrm{~g} \mathrm{~cm}^{-2}\right.$ year $^{-1}$ ) than on the coast $\left(\approx 100 \mathrm{~g} \mathrm{~cm}^{-2}\right.$ year $\left.{ }^{\prime}\right)$ (Bromwich, 1988). Therefore, the surface relief (sastrugi) and scouring by wind may erase the annual isotope signal. In addition, vapor-phase diffusion of $\mathrm{HDO}$ and $\mathrm{H}_{2}{ }^{18} \mathrm{O}$ in the firn smooths short-length isotope events Johnsen. 1983; Whillans and Grootes, 1985). There is no scasonal variation in the isotopes nor in other species recorded in ice) at Vostok, Dome G or Komsomolskaya. The dating of these cores cannot rely on annual layer counting.

Ice-flow models within the Holocene period

The chronology of the deep ice cores is established by iceflow models. The one-dimensional model of Dome $\mathrm{C}$ only accounts for vertical thinning under a constant strain rate. 

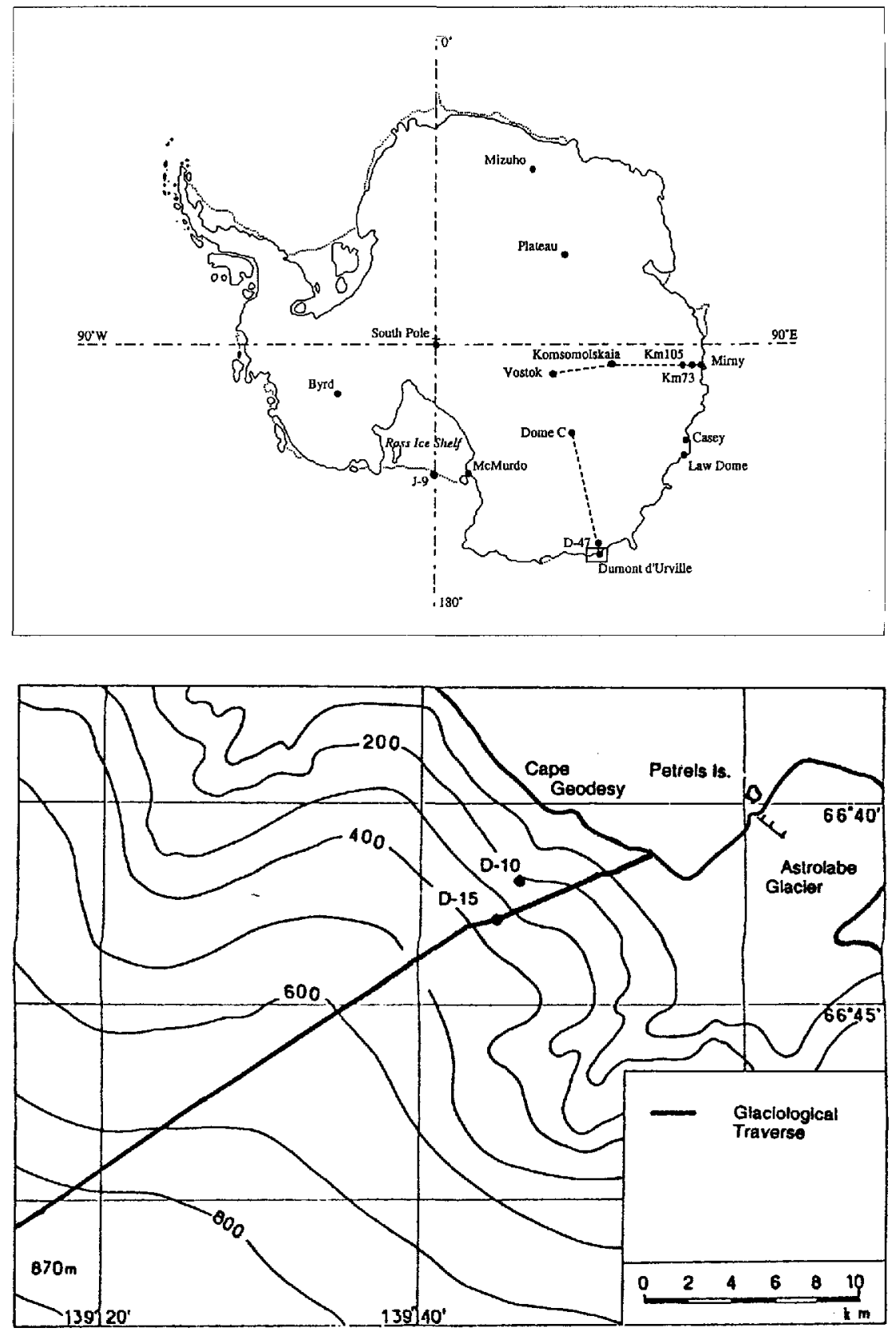

Fig. 1. Map of Antarctica wilh location of the drilling sites.

The two-dimensional model of Vostok accounts for horizontal flow (Lorius and others, 1985; Ritz, 1992). At Dome $\mathrm{C}$ and Vostok, because of the slow motion and great thickness of the ice sheet, the dating of the Holocene ice depends essentially on the accumulation rate. Currently, it is assumed that the amount of water vapor available for precipitation is controlled by the inversion temperature (T) (Lliboutry, 1965; Robin, 1977). The accumulation decreases during cold periods and increases during warm periods. A quantitative formulation of this argument is given by Equation (1) (Lorius and others, 1985):

$$
b(z, t)=b(z, 0) \frac{\partial P_{\mathrm{s}} /\left.\partial T\right|_{T(l)}}{\partial P_{\mathrm{s}} /\left.\partial T\right|_{T(t=0)}} .
$$

$b(z, t)=$ accumulation rate at depth $z$ and time $t$, $P_{s}(T)=$ saturation water-vapor pressurc.

Using Fquation (1), Jouzel and others (1989) dated two ${ }^{10} \mathrm{Be}$ peaks measured both on Dome $\mathrm{C}$ and Vostok at 35000 years $\mathrm{BP}$ and revised the maximum age of Dome $\mathrm{C}$ by 5000 years. They reached the conclusion that the dating over the last climatic cycle of both cores was approximately correct and only needed minor adjustments. When it comes to the Holocene period, where a more precise dating is needed, the validity of Equation (1) becomes questionable. Indeed, ice-flow models based on Equation (1) have yielded an artificial lag of 1500 years for the Vostok record with respect to Dome $C$ within the deglaciation (Ciais and others, 1992). Recently, the Vostok dating has been refined using new accumulation measurements on the flowline upstream from the drilling site (Jouzel and others, 1993). In this study, we use the new EGT (extended glaciological time-scalc) for Vostok which reduces the lag with Dome $\mathrm{G}$ during the deglaciation to 500 years.

Lacking reliable accumulation data for 1991, the earlier dating of Komsomolskaya was arbitrarily cor- 

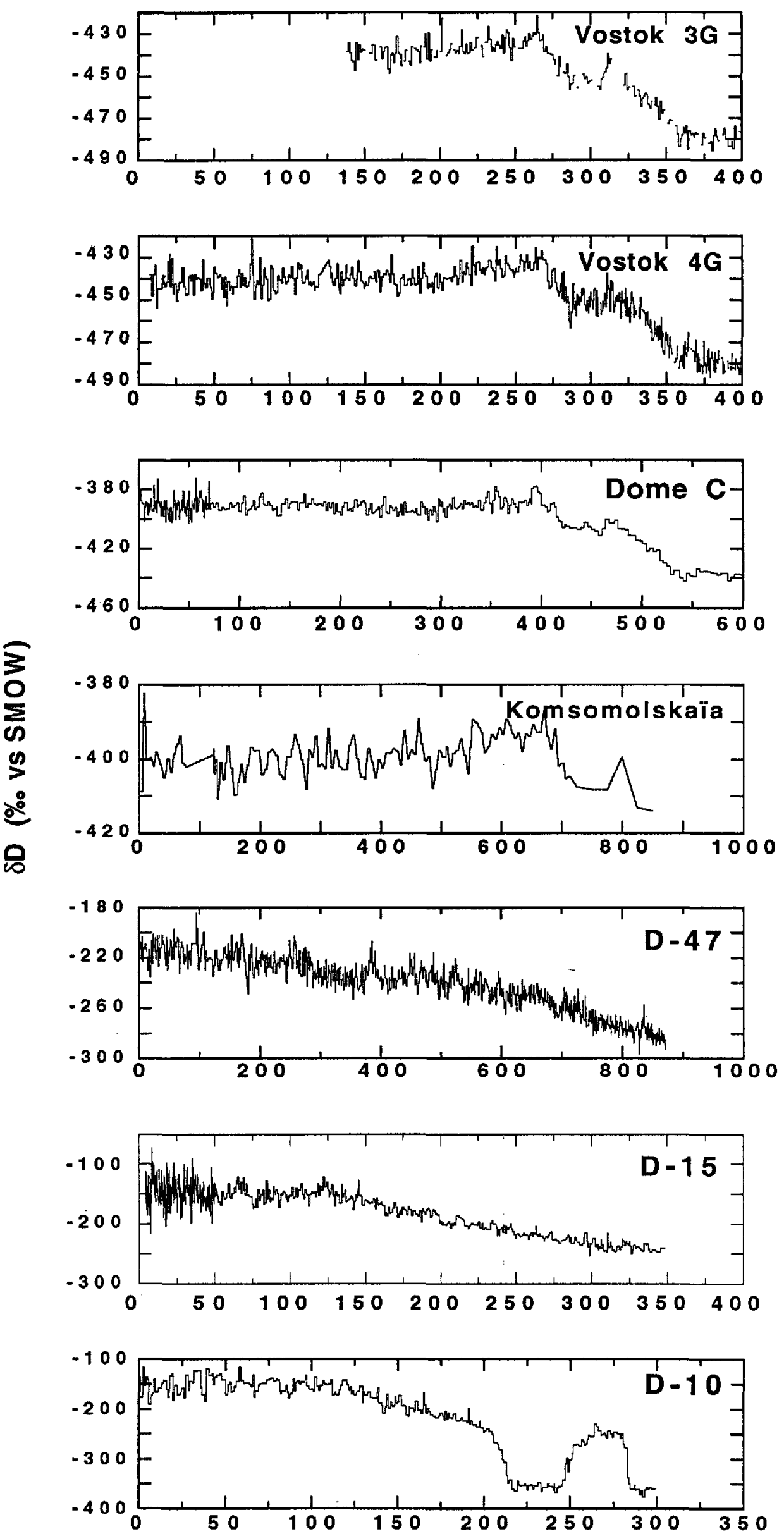

Fig. 2. Isotope profiles (us depth) for seven Antarctic ice cores: coast ice cores are D-10,D-15 and D-47; deep ice cores are Vostok $3 G$ and $4 G$, Dome $C$ and Komsomolskaya. Note that only D-10 is drilled to the bedrock and show's the ClacialHolocene climatic transition (the amplitude is more than three times higher than for Vostok or Dome C). Upper $400 \mathrm{~m}$ dala are showen for Vostok and upper $600 \mathrm{~m}$ for Dome $C$. 


\section{Deep ice cores dating in the Deglaciation}

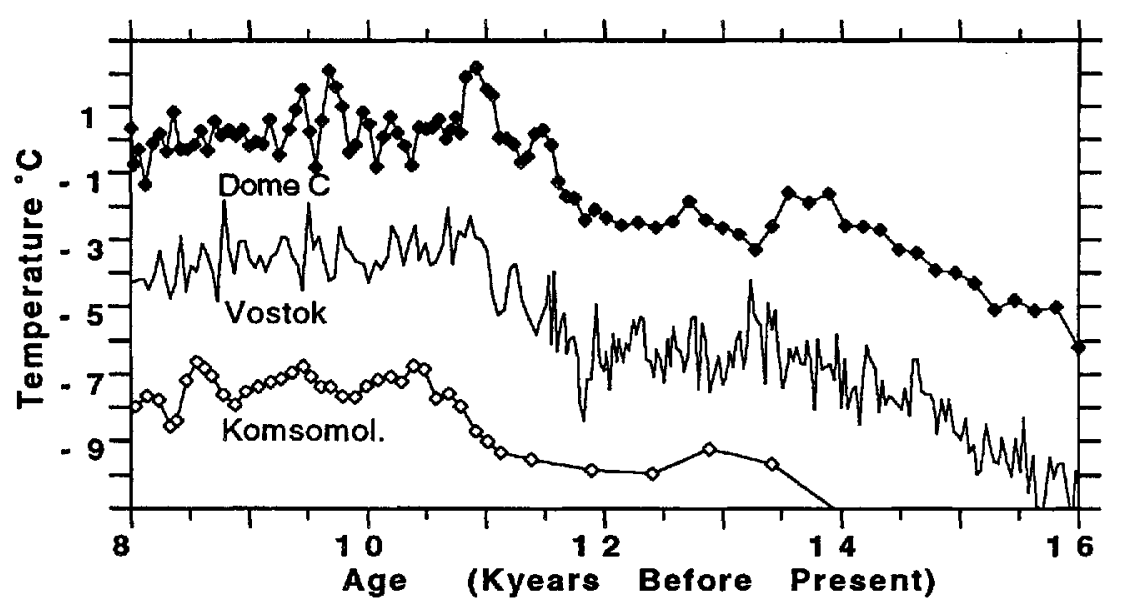

Fig. 3. Dome C, Vostok and Komsomolskaya isotope profiles betwen 8000 years BP and 18000 years BP. Each core is dated independently using a regional ice-flow modeling technique and modern accumulation-rate measurements (Table 1). Timescate discrepancies do not exced 500 years between the three profiles.

related with Dome C (Ciais and others, 1992). We use now an accumulation of $6.54 \mathrm{~g} \mathrm{~cm}^{-2}$ year $^{-1}$ provided by M. Pourchet ( $\beta$ technique) in a Nye ice-flow model. The new Komsomolskaya chronology relates within 400 years to the chronology of Vostok (Fig. 3). The respective chronologies of Vostok, Dome C and Komsomolskaya are all in good agreement at the onset of the Holocene. Comparison of the $\delta \mathrm{D}$ profiles suggests an age difference that does not exceed 300 years at 11000 years BP.

\subsection{Coast ice cores}

D-47: ice-floze model and seasonal variations in $\delta D$

Dating of the $1-47$ ice core is complicated by the fast motion of the ice (decreasing trend of $\delta \mathrm{D}$ with depth) shown in Figure 2. The absence of characteristic discontinuity in $\delta 1)$ shows that the core does not reach into the Pleistoccne. The regional flow-boundary conditions are (1) the accumulation rate upstream of the corc sitc, (2) the divergence of the flowlines, (3) the topography of the bedrock and of the ice-sheet surface, and (4) the ice rheology. We have adapted the twodimensional model for Vostok (Ritz, 1992) to the flowline of 1)-47. Ice trajectories are back-calculated until the "origin" of the ice (upstream location where the ice was deposited) is determined. We obtain in that manner several age- $Z$ curves that correspond to different assumptions for the boundary conditions. These curves can be very different. A detailed sensitivity study shows that boundary conditions (1) and (2) play the major role in the calculation of the age- $Z$ curve (Ciais, 1991). This is probably because the ice of 1)-47 is distant enough from the bedrock for basal-flow complications not to occur. We used regional accumulations from the well-documented data set of $\beta$ measurements by Pettre and others (1986). We estimated the regional flow divergence from the surface elevations (Lorius and others, 1967; Drcwry, 1983) and hypothesized no change in the divergence with depth.

Still, the uncertainty of the model boundary conditions yields age $Z$ curves that differ by almost a factor of 2 (Fig. 4). An appropriate constraint is raised by high- resolution $\delta \mathrm{D}$ measurements on selected parts at discrete depths along the core (every $100 \mathrm{~m}$ ). Each high-resolution $\delta \mathrm{D}$ scries is a $3 \mathrm{~m}$ long ice scgment sampled every $2 \mathrm{~cm}$. From the preserved isotopic cycles (seasonal variations), we calculated a mean annual-layer thickness using the maximum entropy spectral-analysis method Johnsen, 1978. Annual-layer thicknesses are used to constrain iceflow model calculations and therefore allow us to select the exact age $-Z$ relationship with an error of approximately $10 \%$ (Fig. 4). The age of the D-47 ice core is determined as 7500 years BP.

$D-15$ and D-10: ice-flow model and stratigraphic correlation At D-10 and D-15, the reduced thickness of the ice sheet makes the bedrock topography and the rheology as important as the accumulation and divergence in determining the chronology. Also, large variations in the ice thickness could have occurred during the Holocene. For D-10, we forced the agc $-Z$ calculated by our two-dimensional regional model to put the termination of the $\delta \mathrm{D}$ discontinuity at 11000 years $\mathrm{BP}$ (according to the Dome $\mathrm{C}$ profile). D-15 does not reach into the Glacial. At the bottom of the core, $\delta \mathrm{D}(-245 \%)$ is equal to the value observed for the onset of the Holocene at D10. Because D-15 and D-10 are located $2 \mathrm{~km}$ apart and the present-day ice velocity is $10 \mathrm{~m}$ year $^{-1}$, we datcd D. 15 by fixing the bottom of the core to the onset of the Holocene.

\section{ISOTOPE-TEMPERATURE-TRANSFER FUNCTION}

\subsection{Isotope-temperature relationship}

\section{Relation between $\delta$ and $T$ at present and in the past}

In cold ice-shect regions, the average $\delta$ of surface snow is a linear function of local temperature. A regression of the data collected in Antarctica gives a value of $6.04 \% 0{ }^{\circ} \mathrm{C}^{-1}$ for the $\delta \mathrm{D} \cdot T$ gradient (Lorius and Mcrlivat, 1977; Qin Dahe and others, 1994). The observed decrease of $\delta$ with $T$ in polar snowfall is due to the cumulative effect of 


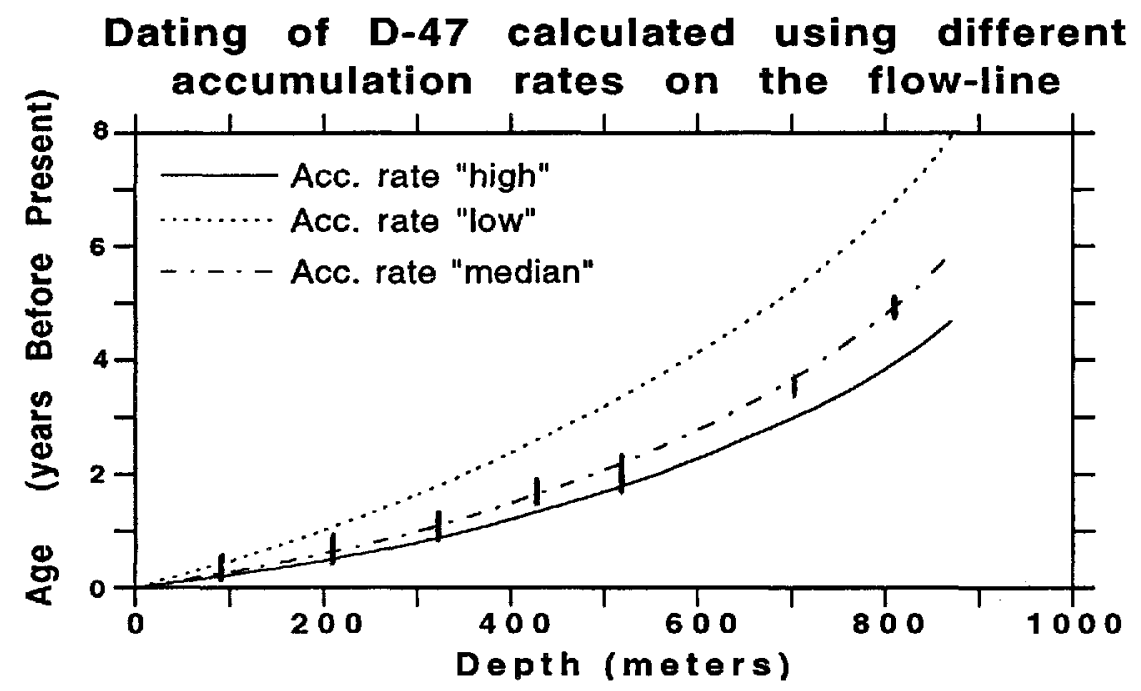

Fig. 4. Ice-flow model time-scales calculated for the D-47 ice core under different accumulation rates parameterization.
Accumulation scenarios are based on measurements made on the D-47 flowline by Pettre and others (1986) ("median"
case), idem plus standard deviation ("high" case), idem minus standard deviation ("low" case). Note the large sensitivity
of the model to the accumulation-rate parameter. Vertical bars mark the isotopic constraints on the ages (see section 2.2).

condensation events that deplete the water vapor above the ice sheet in isotopes (Dansgaard, 1964). The stability of the $\delta-T$ gradient in the past can be tested using general circulation models where water isotopes can be run under realistic climate-boundary conditions (Joussaume and others, 1985; Jouzel and others, 1987a). Joussaume and Jouzel (1993) recently found that the $\delta-T$ gradient in Antarctica during the last glacial maximum was not very different from today. Dealing with stable climates during the Holocene, it is reasonable to use the observed present $\delta T$ gradient to reconstruct past temperatures. Complications arise in coastal regions where the $\delta-T$ relationship only prevails above $1000 \mathrm{~m}$ elevation (Lorius and Merlivat, 1977). D-47 is located above $1000 \mathrm{~m}$ and $\delta \mathrm{D}$ along the core rccords temperature. For D-15 and D-10, onc can sce in Figure 2 that only the ice from upstream regions above $1000 \mathrm{~m}$ depth (now at a depth below $120 \mathrm{~m}$ in $\mathrm{D}-15$ ) shows a characteristic decrease of $\delta \mathrm{D}$ with depth. After our dating of the core, surface ice for which $\delta \mathrm{D}$ is a dubious proxy of tempcrature is no older than 700 years. In this study, we do not discuss the climate of the last millennium but the fluctuations during the last 10000 years, and the core of D-15 is a reliable indicator of temperature over this time period.

\section{Biases in isotope records}

We examine three systematic biases of the temperature information contained in the isotopes. (1) Changes in ice thickness and ice flow cause a displacement of the origin of the ice which may affect the isotope record. Over central Antarctica, Holocene variations in the thickness of ice are probably negligible (Vostok elevation did not change by more than $100 \mathrm{~m}$ over the last climatic cycle). Over coastal Antarctica, the ice-flow model we used to date D-47 was in agreement with the isotopic constraints on the dating only if elevation changes were less than $200 \mathrm{~m}$ (Ciais, 1991). At the edge of the ice sheet, the Holocene isotope records of D-15 and D-10 are ccrtainly affected by changes in icc thickncss (Grootes and Stuiver, 1987). We attribute millennium-scale variations in $\delta \mathrm{D}$ to temperature changes, whereas the global trend of $\delta \mathrm{D}$ with depth integrates past changes in thickness and ice flow. (2) Changes in tcmperature at the moisture source influence $\delta$ of $A$ ntarclic snowfall. $A 1^{\circ} \mathrm{C}$ increase in SST has the same effect on $\delta \mathrm{D}$ over central Antarctica as a local temperature decrease of $0.7^{\circ} \mathrm{C}$ (Koster and others, 1992). A systematic correction would have to account for past variations in the SST at the moisture source. However, central Antarctic moisture likely originates from sub-tropical latitudes (Petit and others, 1991; Koster and others, 1992) where SST shows little change in the past (CLIMAP, 1981). No SST correction in the past is applied to coastal cores. (3) Changes in the isotope composition of the surface ocean offset $\delta$ in Antarctic precipitation. This is corrected using the marine $\delta^{18} \mathrm{O}_{\text {sta }}$ record (Laberyrie and others, 1987) scaled by a factor of 8 for deuterium (Craig and Gordon, 1965). Over the past 10000 years, this corrects the Antarctic temperature by $0.2^{\circ} \mathrm{C}$.

\subsection{Noise in the isotope-temperature relationship}

\section{$\delta$ T noise and $\delta$ noise}

There is a random dispersion on the $\delta-T$ transfer function that we call $\delta-T$ noise. Its variance, $\operatorname{Var}\left(N_{\delta-T}(t)\right)$, represents a threshold below which a fluctuation in $\delta$ is not significant in terms of temperature. Processes entering in $\delta-T$ noise are listed in Table 2 (after Robin (1979)). Lacking micro-meteorological data and surface-relief data at the drilling sites, it is very difficult to estimatc directly $\operatorname{Var}\left(N_{\delta}, T(t)\right)$ from the variance of each process. One possibility is to cxamine two parallel cores at the same site. The isotope profiles measured on two such cores are not perfectly correlated, which defines a $\delta$ noise, $N_{\delta}(t)$. Generally, $\operatorname{Var}\left(N_{\delta-T}(t)\right)$ is larger than $\operatorname{Var}\left(N_{\delta}(t)\right)$, because it contains more processes (see Table 2). We have assumed that these extra processes entering in $\operatorname{Var}\left(N_{\delta-T}(t)\right)$ are much less important than the spatial irregularity in the deposition, given the very low accumulation observed in central Antarctica (Bromwich, 1988). Therefore, we make the approximation: 
Table 2. Process entering in the $\delta$ noise and $\delta-T$ noise

$$
\delta \text { noise }
$$

$\delta-T$ noise

Noise on $\delta$ inferred from taw Noise on the $\delta-T$ relationship adjacent cores

Irregular deposition

Precipitation scattering

+ weind effects

Isotope smoothing

Summer melting

Core processing
Irregular desposition

Precipitation scatlering + wind effects

Isotope smoothing

Summer melting

Core processing

Variations in the winter/ summer deposition

Variations of $T$ not recorded in $\delta$ such as Inversion strength + storms frequency

Long-term variations in the $\delta-T$ relationship such as Moisture origin + air-masses trajectories

$$
\operatorname{Var}\left(\mathrm{N}_{\delta-\mathrm{T}}(\mathrm{t})\right) \approx \operatorname{Var}\left(\mathrm{N}_{\delta}(\mathrm{t})\right)
$$

\section{Isotopic noise at Vostok}

The drilling of the adjaccnt cores $3 \mathrm{G}$ and $4 \mathrm{G}$ makes it possible to estimate directly $\operatorname{Var}(N(t))$. To do so, we decomposed $\delta_{i}$ of each core as the sum of a climatic signal $\delta_{i}{ }^{c}(t)$, common to both cores, plus random noise (Fisher and others, 1985):

$$
\delta_{i}(t)=\delta_{i}{ }^{c}(t)+N_{i}(t) \quad i=3 \mathrm{G}, 4 \mathrm{G} .
$$

Both cores, within a distance of $100 \mathrm{~m}$, have the same deposition conditions, which yields:

$$
\operatorname{Var}\left(N_{3 \mathrm{G}}(t)\right)=\operatorname{Var}\left(N_{4 \mathrm{G}}(t)\right)
$$

and from Equation $(3) \operatorname{Var}\left(\delta_{3 \mathrm{G}}(t)\right)=\operatorname{Var}\left(\delta_{4 \mathrm{G}}(t)\right)$.

From the definition of the $3 G-4 G$ correlation coefficient $\left(R_{3 \mathrm{G}-4 \mathrm{G}}\right)$, we then obtain

$$
\operatorname{Var}(N(t))=\left(1-R_{3 \mathrm{G}-4 \mathrm{G}}\right) \operatorname{Var}(\delta(t)) .
$$

Estimating $\operatorname{Var}(N(t))$ from Equation (5) over the interval 0-15000years BP, we obtained a correlation that was not statistically significant, yielding a noise variance of $15 \%$ in $\delta 1$, a value larger than the expected "climatic" variance during the Holocene (the deglaciation represents about $40 \%$ ). This shows that the shortterm variability of temperature cannot be extracted from the noise on $\delta$. Therefore, we must choose an arbitrary time-scale for the $T$ fluctuations we want to study. Table 3 shows that the signal/noise ratio is larger than 1 only when periods shorter than 200 years are cut off (one core sample is $\approx 50$ ycars). 'Lo study Holocene temperature changes, we adopted a cut-of period of 500 years (signal/ noise $=4$ ). This focuses our discussion on events typically of the same duration as the Little Ice Age. To translate this in terms of an error bar on the reconstructed temperature, we considered the $\delta-T$ relation (corrected from ocean composition):

$$
T=\frac{\delta-51+\Delta \delta_{\mathrm{sca}}}{6.04}
$$

$\Delta \delta_{\text {sea }}$ is the difference between the past ocean $\delta^{18} \mathrm{O}$ and present-day SMOW. From the experimental error, $\operatorname{Var}\left(\Delta \delta_{\text {sea }}\right)=0.1 \%$ o $(0.8 \%$ in $\delta \mathrm{D})$. Equation (5) gives a noise variance of $2.2 \%$.

Table 3. Noise on time series of $\delta D$ at Vostok

\begin{tabular}{cccc}
\hline Low-pass cut-off period & $\sigma \delta=$ & $\sigma N \delta=$ & $\sigma N T={ }^{\text {Signalinoise }}$ \\
years & $\% D$ standard deviation & $\delta$ noise standard devialion & $T$ noise standard deviation \\
ratio & $\% 0$ & ${ }^{\circ} \mathrm{C}$ \\
\hline
\end{tabular}

Core $3 \mathrm{G} \quad$ Core $4 \mathrm{G} \quad R_{3 \mathrm{G}-4 \mathrm{G}}$

$\begin{array}{rrrrrrr}50^{*} & 4.65 & 4.72 & 0.37 & 3.71 & 0.61 & 0.6 \\ 100 & 4.19 & 3.99 & 0.53 & 2.81 & 0.47 & 1.2 \\ 200 & 3.93 & 3.79 & 0.67 & 2.21 & 0.36 & 2.0 \\ 300 & 3.44 & 3.44 & 0.73 & 1.78 & 0.30 & 2.7 \\ -400 & 3.30 & 3.36 & 0.77 & 1.60 & 0.26 & 3.4 \\ 500 & 3.21 & 3.30 & 0.79 & 1.49 & 0.24 & 3.8 \\ 1000 & 2.55 & 2.98 & 0.82 & 1.17 & 0.19 & 4.6\end{array}$

\footnotetext{
* Original data sampling.
} 


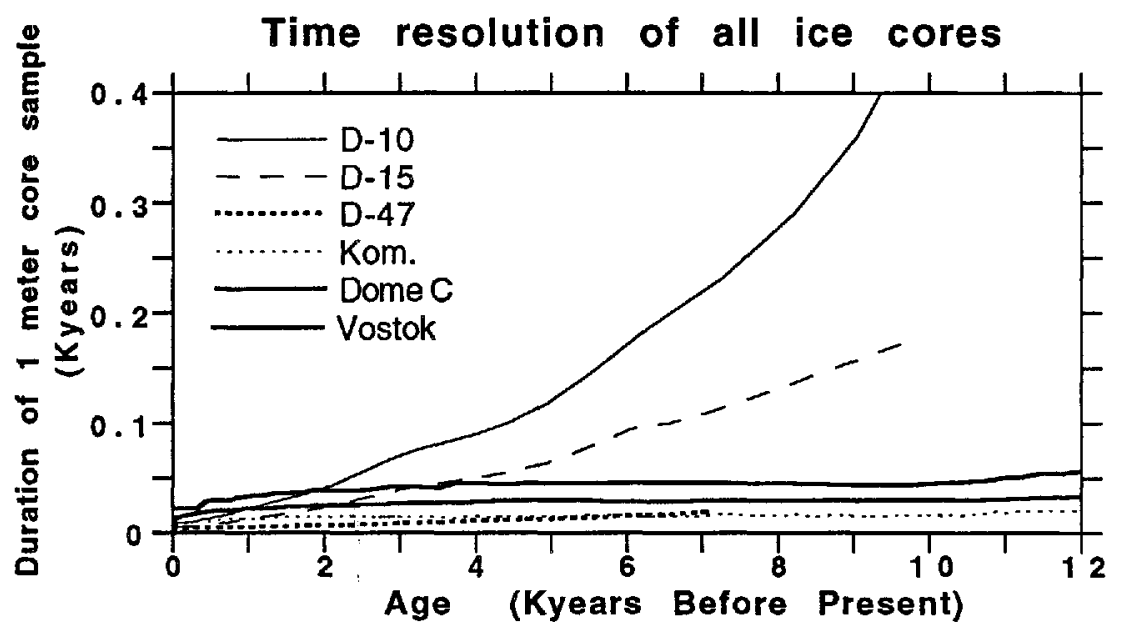

Fig. 5. Average number of years contained in a $1 \mathrm{~m}$ long sample for six Antarctic ice cores (i.e. derivative $\partial \mathrm{age} / \partial z$ ). The smaller the number of years, the betler the time resolution of the core. Nole that coast ice cores have a better time resolution during the late Holocene period and deep ice cores during the early Holocene.

$$
\begin{aligned}
\operatorname{Var}\left(N_{T}(t)\right) & =\frac{\operatorname{Var}\left(\mathrm{N}_{\delta}(\mathrm{t})\right)+\operatorname{Var}\left(\mathrm{N}_{\Delta x}(\mathrm{t})\right)}{6.04^{2}} \\
& =\frac{2.2+0.8}{6.04^{2}}=0.082^{\circ} \mathrm{C}^{2}
\end{aligned}
$$

This turns into a standard deviation of $0.25^{\circ} \mathrm{C}$ which represents physically the threshold bclow which a variation in temperature derived from the isotope record is not signilicant when dealing with isotope data filtered at 500 years. This value is intuitively an upper cstimate of the isolopic noise in Antarctica because Vostok has the lowest accumulation. At Dome $\mathrm{C}$, based on the dispersion of $\delta \mathrm{D}$ on 20 surface cores, Ciais (1991) estimated an isotopic noise of $0.3^{\circ} \mathrm{C}$ (data filtered at 500 years). In coastal regions, one would expect the snow deposition to show less scatter than inland, because of larger accumulations. However, this may be counterbalanced by substantial wind scouring of freshly depositcd snow (Wendler, 1989; Parish and Wendler, 1991). From the oD variability of surface cores, we provided a rough estimate of the noise variance at $\mathrm{D}-47$ of $0.2-0.3^{\circ} \mathrm{C}$ (Ciais, 1991).

\section{HOLOCENE ANTARCTIC CLIMATE}

\subsection{Paleo-temperature reconstruction}

\section{Distortion due to ice-core sampling}

The core-sampling increment for isotopes is constant with depth. Therefore, becausc of the vertical ice thinning, one sample represents more years at greater depths. The number of years contained in a given sample, which characterizes the time resolution of the core, is calculated from the age $Z$ function, $A(Z)$, and the sampling increment, $l$, using Equation (9):

$$
\Delta t=l \times \mathrm{d} A / \mathrm{d} Z .
$$

$\Delta t$ as a function of $Z$ is shown for all cores in Figure 5. Deep ice cores have an almost constant $\Delta t$, because Holoccne icc is high above the bedrock and does not undergo strong vertical thinning. In contrast, coastal ice cores are characterized by a strong increase in $\Delta t$ with depth. In the case of D-10, for instance, a $1 \mathrm{~m}$ long sample contains $\approx 2$ years near the surface and $\approx 500$ years at $Z=200 \mathrm{~m}$. To present our records in a manner that is not distorted by ice-flow-induced thinning, the data were digitized to create an annually sampled time serics, which was filtered to remove periods of less than the maximum value of $\Delta t$ along the core. A cut-off period of 500 years was found to satisfy both requirements of the noise and of the sampling (Fig. 6).

\subsection{Antarctic temperature trends}

Average lemperalure curve

We observed that intervals characterized by colder temperatures can be correlated in most of the curves and we derived an "average temperature" curre. lemperature fluctuations do not exceed $1-2^{\circ} \mathrm{C}$ in any

Temperature record of each core

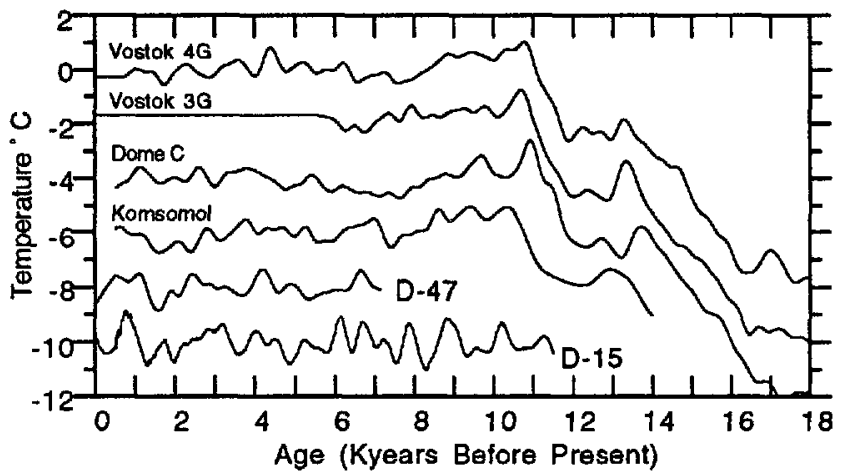

Fig. 6. Temperature reconstructed from the isotope profile of six Antarctic ice cores. Isotope data hare been filtered in order to remove all periods shorter than 500 years to minimize the noise on the data. Temperalure variations are expressed as the departure from the mean value over the past 5000 years. A constant offset has been added to each profile for display clarity. The D-10 reconstructed temperature showes flucutations of magnitude $3-4^{\circ} C$ as a consequence of discontimuous sampling of the core and is not included. 
core (large variations at $\mathrm{D}$ - 10 are likely to be due to the non-continuous sampling of the core and D-10 is excluded from the averagc). From Figure 5 , it is secn that the climate of the early Holocene is better resolved in the deep ice cores, whereas the late Holocene is better resolved in coastal ice cores. We have attributed to each time series a weight $w_{\text {i }}$ proportional to its time resolution $\Delta t_{\mathrm{i}}$ as defined by Lquation ( 8 )

$$
w_{\mathrm{i}}=\left(\Delta t_{\mathrm{i}}\right)^{-1} / \sum_{j=1}^{6}\left(\Delta t_{j}\right)^{-1} \text {. }
$$

The weighted average temperature, $\bar{T}(t)$, is then expressed by:

$$
\bar{T}(t)=\sum_{j=1}^{6} w_{j} T_{j}(t) .
$$

$\bar{T}(l)$ is shown in Figure $\overline{7}$. Considering a wcighted average in place of a simple average does not change the timing of the $T$ fluctuations, although it has the effect of changing their amplitude in such a manner that $\bar{T}(t)$ is dominated by Vostok and Dome $\mathrm{C}$ in the early Holocene, and by D-47 and D-15 in the late Holocene. Maximum temperatures ( ${ }^{\circ} \mathrm{C}$ warmer than today) prevail between 11000 and 8000 years BP, defining an early Holocene optimum (Ciais and others, 1992). The most significant cooling is from 8000 to 5500 years BP. The late Holocene is characterized by a stablc average temperature. A noticeably warmer climate episode occurred around 4000 years BP. An important cooling occurred between 2000 and 1000 years BP.

Comparison with the Byrd ice-core record, West Antartica The Byrd $\delta^{18} \mathrm{O}$ (see for instance, Johnsen and others, 1972 ) shows a rapid increase of $1.5 \%$ at 4500 years BP, which is absent from the East Antarctic corcs. Assuming a $\delta^{18} \mathrm{O}-\mathrm{T}$ gradient of $0.8 \%{ }^{\circ} \mathrm{C}{ }^{1}$, this increase translates into a regional warming of $2 \mathrm{C}$. A change in the ice thickness (thinning of $200 \mathrm{~m}$ ) or in the moisturc supply to Nest Antarctica is more likely to have occurred.

\section{Average Temperature}

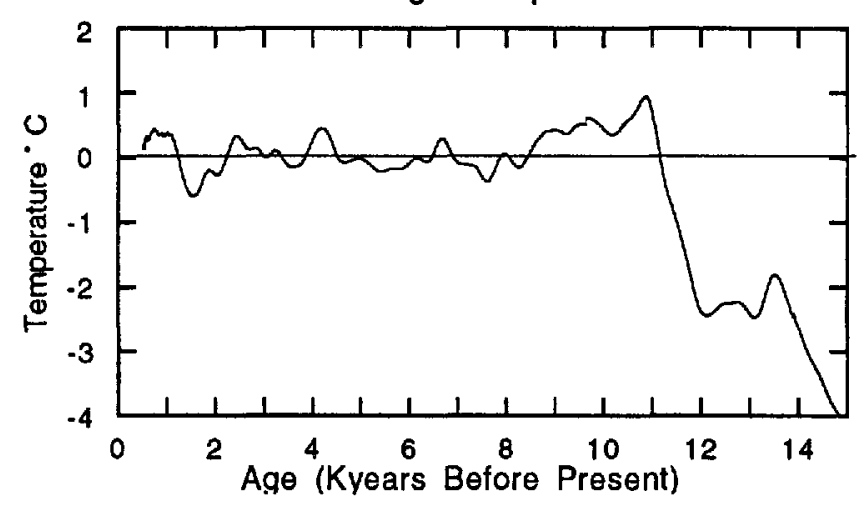

Fig. 7. Average temperature cure from six Antarctic ice cores (Fig. 6). Core D-10 is not included. A different weight has been given to each record according to the quality of its time resolution (Fig. 5). Temperature is expressed as the deparlure from the mean over the past 5000 years.
Early Holocene Antarctic climate and "Holocene optimum"

Evidence for maximum tempcratures during the first 2000 years of the Holocene contradicts the commonly admitted picturc of a worldwide mid-Holocene optimum (Lamb, 1977; Folland and others, 1990). If higher $\delta \mathrm{D}$ in Antarctica did not reflect warmer tcmperatures, then one would have to look for changes in (1) clcvation and ice flow, (2) moisture source and (3) source composition. Our curves are already corrected from (3). Regarding point (2), isotopic models demonstrate that SST influences $\delta \mathrm{D}$ according to Koster and others, 1992)

$$
\Delta \delta=6 \Delta T_{\mathrm{p}}-4 \Delta T \mathrm{e} .
$$

$T_{e}=$ sea-surface temperature, $T_{\mathrm{p}}=$ site tompcrature.

The SST in the Southern Occan werc warmer than today during the early Holocene, as inferred from the marine rcoord (Hays and others, 1976; Iabracherie and others, 1989). This would yield even warmer Antarctic temperatures in the early Holocene. Point (1) can be discussed qualitatively, provided that the central EAIS did not change by more than $\pm 200 \mathrm{~m}$ during the climatic transition (Huybrecht, 1990; Martinerie, 1990). Greater $\delta \mathrm{D}$ values during the early Holocene could be attributed to a change in elevation if the EAIS remains thinner than today up to 8000 years BP, and then thickens rapidly to reach its present characteristics. This would translate into a change in accumulation of $10 \mathrm{cmyear}^{1}$ at around 8000 years BP, which is not compatible with the isotope data (Equation (1)). A step further would be to compare our Antarctic temperature record with the climate of high southern latitudes over the past 15000 years. There are terrestrial and marine ${ }^{14} C$ dated paleoclimate records in South America, New Zcaland, Tasmania and in the Southern Ocean.

\section{CONCLUSIONS}

In the six ice cores examined in this work, the Holocene period is characterized by fairly constant $\delta \mathrm{D}$ values. Because the climate signal contained in the isotopes is embedded in a strong noise (irregular snow deposition), the data wore filtered to minimize the signal/noise ratio. The average temperature curve shows warmer conditions than at present during the Holocene interval ( 11000 and 9000 years BP by about $1-2^{\circ} \mathrm{C}$. The late Holocene period is characterized by shorter fluctuations, the most noticeable bcing a warm peak around 4500 years BP and a cold interval around 2000 years BP.

We have restricted the present study to the isotopes, a proxy primarily related to local changes. Variables of more global character (gases and chemical impurities) are also reconstructed from icc cores. Thcy relate to past atmospheric composition and circulation, as well as to the emission by sources. Within the Holocene interval, the concentration of dust is fairly constant but $\mathrm{CO}_{2}$ and $\mathrm{CH}_{4}$ appear to be higher during the early Holocene, concomitant with the local maximum in temperature. A better knowledge of the Holocene from the ice-core record can be placed in perspective with an abundance of paleoclimate reconstructions worldwide. Hopefully, this 
will help to explain why climate conditions have been so remarkably equable over the past 10000 years in contrast to the large and rapid changes observed during Glacial and late-Glacial periods.

\section{REFERENGES}

Bromwich, D. H. 1988. Snowfall in high southern latitudes. Rev. Geophys., 26. $149-168$.

Ciais, P. 1991. Forages profonds et sites côtiers en Antarctique: données isotopiques et climat des 15,000 dernières années. Ph.D. thesis, University of Paris VI

Ciais, P. and 6 others. 1992. Fividener for an carly Holocene climatic optimum in the Antarctic deep ice record. Chm. Dynam., 6, 169-177

CLIMAP. 1981. Seasonal reconstructions of the Earth's surface al the last glacial maximum. Boulder, CO, Geological Society of America.

Craig, $\mathrm{H}$. and $\mathrm{A}$. Gordon. 1965. Deuterium and oxygen 18 variations in the ocean and the marine atmosphere. In Spoleto, E.T., ed. Stable isotopes in oceanic studies and paleotemperatures. Pisa, Consiglio Nazionale della Riserche, 9-130.

Dansgaard, W. 1964. Stable isotopes in precipitation. Tellus, 16 4i, 436-468.

Drewry, D.J., ed. 1983. Antarctica: glaciological and geophysical folio. Cambridge, Lniversity of Cambridge. Scott Polar Research Institute

Fisher, J). A., N. Rech and H. B. Clauscn. 1985. Stratigraphic noisc in time series derived from ice cores. Ann. Glaciol, 7, 76-83.

Folland. C. K., 'I'. R. Karl and K. Y. Vinnikot. 1990. Observed climate variations and change. In Houghton, J. T., ed. Climate change, the IPCC scientific arsessment. Cambridge, Cambridge Lniversity Press, 198-238.

Grootes, P. and M. Stuiver, 1987. Ice sheet elevation changes from isotope profiles. Intemational Association of Hydrological Sciences Publication 170 Symposium at Vancouver, 1987 -.. The Physical Basis of Ie Shect Modelling), 269-281.

Havs, J. D.. J. Imbrie and N. J. Shackleton. 1976. Variations in the Viarth's orbit: pacemaker of the ice ages. Science, 194(4270), $1121 \cdot 1132$.

Huybrecht, P. 1990. The Antarctic ice sheet during the last glacialinterglacial cycle: a three-dimensional experiment. Ann. Glaciol, 14 , $11 . \overline{5}-119$.

Johnsen, S.J. 1978. On power estimation in maximum entropy spectral andalysis. Geoplysics: 43, 681-690.

Johnsen, S.J. 1983. Glaciological parameters, their measurements and significance: diffusion of stable isotopes. In Robin, G. de Q ed. The dimatic record in polat ice shets. Cambridge, Cambridge University Press, 57-63.

Johnsen, S. J., W. Dansgaard, I. B. Clausen and C. C. Langway. 1972 Oxygen isotope profile through the Antarctic and Grecnland ics sheets. Viature, 235 $(5339), 129-434$.

Joussaume. S. and J. Jouzel. 1993. Paleoclimatic tracers: an investigation using an atmospheric gencral circulation model under ice age conditions. 2. Water isotopes. J. Geophys. Res., 98(1)2), 2807-2830.

Joussaume, S., J. Jouzel and R. Sadourny. 1985. A general circulation model of water isotope cycles in the atmosphere. Vature, 311 5981;, 24-29.

Jouzel, J., I. Mcrlivat and C. Lorius. 1982. Deuterium excess in an East Antarctic ice core suggests higher relative humidity in the oceanic surface during the last glacial maximum. Nature, 299/5885 , 688691.

Jouzel, J., G. L. Russell, R.J. Suozzo, R. D. Koster, J. W. C. Whitr and W.S. Brocker. 1987a. Simulations of the $\mathrm{HDO}$ and $\mathrm{H}_{2}{ }^{18} \mathrm{O}$ atmospheric cycles using the NASA/GISS general circulation model: the scasonal cycle for present-day conditions. 7. Geophys. Res., $92(1) 12), 14.739-14,760$.

Jouzel, J. and 6 others. $1987 \mathrm{~b}$. Vostok ice core: a continuous isotope temperature record over the last climatic cycle (160:000 years). Vilure, 329 6138$)$, 403-408.

Jouzel, J and 9 others. 1989. A comparison of deep Antarctic ice cores and their implications for climate between 65,000 and 15,000 years ago. Qual. Res., 31 ), 135-150.
Jouzel, J. and 16 others. 1993. Extending the Vostok ice core record of palacoclimate to the penultimate glacial period. Vature, $\mathbf{3 6 4}, 6439$;, $407-412$.

Koster, R. D., J. Jouzel, R. J. Suozzo and G. L. Russell. 1992. Origin of July Antaretic precipitation and its influence on deuterium content: a GCM analysis. Clim. Dyam., 7, 195-203.

Labeyrie, L. D., J.C. Duplessy and P.L. Blanc. 1987. Variations in mode of formation and temperature of occanic deep waters over the past 125,000 ycars. Fature, 327 6122), 477-482.

Labracherie, M. and 6 others. 1989. The last deglaciation in the Southern Ocean. Paleoceanography, 4, 629-638.

Lamb, H. H. 1977. Climate: present, past, and futwe. London, Mcthucn.

Legrand, M. and R.J. Delmas. 1987. A 220-year continuous record of volcanic $\mathrm{H}_{2} \mathrm{SO}_{4}$ in the Antarctic ice sheet. Vature, 327 6124), 671676 .

Lliboutry, L. 1965. Traité de glaciologie. Tome II. Paris, Masson.

Lorius, C. and I. Merlivat. 1977. Distribution of mean surface stable: isotope values in East Antarctica: observed changes with depth in the coastal area. Intemational Association of Iydrological Sciences Publication 118 Symposium at Grenoble 1975 Isolopes and Impurities in Snox and I.e), $127-137$.

Lorius: C., G. Rouillor and F. Helly, 1967. TAAF Terre Adelie: campagnes dété 1964-1965, et 1965-1966. Détermination des ćpaisscurs de glace par une méthode gravimćtrique simplifićc. Expéditions Polaires Francaises, Publication 295.

Lorius, C., L. Merlivat, J. Jouzel and M. Pourchet. 1979. A 30,000 yr isotope climatic record from Antarctic ice. Aatury, 280 5724), $644-648$.

Lorius, C, and 6 others. 1985. A 150,000-year dimatic record from Antarctic ice. Mature, 316(6029), 591596.

Martinerie, P. 1990. l'cneur en gaz des glares polaires. Variations géographiques actuelles, variations au cours du demier cycle climalique dans la région de Vostok. (Ph.D. thesis, University of Grenoble.)

Nicolaies, V.I., V.M. Kotlyakos and K. E. Smirnov. 1988. Isotope studies of the ice core from the Komsomolskaia station. Antarctica. Data of Glaciological Sudies of the CSSR Academy of Sciences, 63, 97-102.

Parish, T. and G. Wendler. 1991. The katabatic wind regime at Adélie Land, Antarctica. Int. 7. Climatol, 11, 91-107.

Petit. J. R., J. W. White, N. W. Young. J. Jouzel and Y. S. Korotkeritch. 1991. Deuterium cxcess in recent Antarctic snow. \% Geophys. Res. $96(\mathrm{D} 3), 51135123$.

Pettre, P. J. F. Pinglot, M. Pourchet and I. Reynaud. 1986. Accumulation distribution in Terre Adélie, Antarctica: effect of meteorological parameters. 7. Glaciol., 32 112$)$, 486500.

Qin Dahe, J. R. Petit, J. Jouzcl and M. Sticvenard. 1994. Distribution of stable isotopes in surface snow along the route of the 1990 international Trans-Antarctica Expedition. 3. Glaciol., 40 134;, 107-118.

Ritz, C. 1992. Un modèle thermo-mécanique d'érolution pour le bassin glaciaire Antaretique Vostok-Glacier Byrd: sensibilite aux raleurs des parametres mal connus. (Thèse d'Etat, Lniversity of Grenoble.

Robin, G. de Q. 1977. Ice cores and climatic changes. Phil. Trans. Rol. Sor. Lond., Ser. B, 280, 143-168.

Robin, G. de Q. 1979. Climate into ice: the isotopic record in polar ice sheets. International Association of Iydrological Sciences Publication 131 Symposium at Canberra 1979-Sea Level, Ice and Climatic Change, 207-216.

Wendler, G. 1989. On the blowing snow in Adćlic Land, eastern Antarcica. In Oerlemans, J., ed. Cracier flutuations and climatic change. Dordrecht, Kluwer Academic Publishers, 261-279.

Whillans, 1. M. and P. M. Grootes. 1985. Isotopic diffusion in cold snow and firn. J. Geophys. Res, 90/192, 3910-3918.

The accuracy of references in the text and in this list is the responsibility of the authors, to whom queries should be addressed. 